\title{
Sistem Informasi Akademik pada SMK Tanjung Priok 1 Jakarta
}

\author{
Rifky Permana ${ }^{1}$, Tika Adilah Mutiara² \\ ${ }^{1}$ Sistem Informasi, Teknik dan Informatika, Universitas Bina Sarana Informatika, \\ Jl. Kramat Raya No.98, Senen, Jakarta Pusat \\ Email: rifky.rpp@bsi.ac.id \\ ${ }^{1}$ Teknologi Informasi, Teknik dan Informatika, Universitas Bina Sarana Informatika, \\ Jl. Kramat Raya No.98, Senen, Jakarta Pusat \\ Email: tika.tam@bsi.ac.id

\begin{tabular}{ccc}
\hline Diterima & Direvisi & Disetujui \\
$03-11-2020$ & $09-11-2020$ & $15-12-2020$ \\
\hline
\end{tabular}

\begin{abstract}
Abstrak - Teknologi sistem informasi di era saat ini berkembang sangat pesat, maka setiap orang dituntut untuk dapat menyajikan sistem informasi dengan cepat dan akurat dalam dunia kerja. Dalam hal ini komputer mempunyai peranan yang sangat penting, karena komputer merupakan salah satu media yang paling tepat untuk mempermudah pekerjaan dan dapat menyajikan informasi dengan cepat dan akurat. Begitu juga dengan Sistem Informasi Akademik, diharapkan dapat menyediakan program aplikasi yang tepat, cepat dan akurat dalam mengolah berbagai proses akademik. Sistem Informasi Akademik merupakan aplikasi dalam membantu proses dunia pendidikan. Tujuan pembuatan aplikasi ini adalah untuk membantu pemecahan masalah yang banyak terjadi pada sekolah sekolah. Kasus yang sering terjadi pada sekolah adalah masalah penanganan pengolahan data akademik. Pencarian data dan penyimpanan data. Semakin tingginya frekuensi akademik semakin meningkat pula kebutuhan pengolahan data. Maka dari itu, perancangan program yang dibuat ini dimaksudkan untuk membantu serta meringankan permasalahan yang dihadapi oleh sekolah. Karena perancangan aplikasi ini lebih efektif dan efisien dibandingkan pencatatan yang masih manual. Setelah aplikasi ini siap dan segera diimplementasikan pada SMK Tanjung Priok 1, tentu saja akan berdampak positif dalam pengelolaan dan pengolahan data akademik dimasa yang akan datang.
\end{abstract}

Kata Kunci: Sistem Informasi, Akademik, Aplikasi

\begin{abstract}
Information system technology in the current era is growing very rapidly, so everyone is required to be able to present information systems quickly and accurately in the world of work. In this case the computer has a very important role, because the computer is one of the most appropriate media to simplify work and can present information quickly and accurately. Likewise with the Academic Information System, it is hoped that it can provide an appropriate, fast and accurate application program in processing various academic processes. Academic Information System is an application in helping the process of education. The purpose of making this application is to help solve problems that often occur in schools. The case that often occurs in schools is the problem of handling academic data processing. Data search and data storage. The higher the academic frequency, the higher the need for data processing. Therefore, the program design made is intended to help and alleviate the problems faced by schools. Because the design of this application is more effective and efficient than manual recording. After this application is ready and immediately implemented at SMK Tanjung Priok 1, of course it will have a positive impact in the management and processing of academic data in the future.
\end{abstract}

Keywords: Information Systems , Academic, Application

\section{PENDAHULUAN}

Seiring dengan perkembangan zaman dan perkembangan teknologi, kemampuan komputer dalam memberi solusi bagi permasalahan di berbagai bidang juga harus ditingkatkan. Hampir segala teknologi informasi telah mengalami banyak perubahan kearah yang semakin maju. Perkembangan teknologi informasi dapat memberikan solusi untuk proses pengolahan data nilai pada sekolah.

Sistem pengolahan data nilai akan menjadi tolak ukur untuk menciptakan output yang berkualitas dan mampu bersaing dengan sekolah lain. Salah satu tolak ukurnya adalah penilaian hasil belajar siswa yang biasanya ditangani oleh masing-masin wali kelas. Penilaian dilakukan secara menyeluruh dan berkesinambungan terhadap proses dan hasil belajar sesuai dengan karakteristik mata pelajaran dan jurusan yang mereka pilih sehingga diperoleh informasi nilai yang lengkap, dari nilai-nilai tersebut cara pengolahanya masih dilakukan dengan menggunakan program yang belum terintegrasi dengan database. (Wardani, 2013) 
Dengan sistem informasi diharapkan dapat mempermudah penyampaian informasi akademik khususnya nilai dan prestasi siswa kepada orang tua siswa" (Widhiarso \& Riasti, 2013). Agar dalam proses pendataan di sekolah ini bisa bekerja lebih efektif dan menggunakan sistem informasi sesuai dengan perkembangan teknologi yang dapat membantu mempercepat proses pendataannya (Sugiarti \& Wardati, 2012).

SMK Tanjung Priok 1 Jakarta adalah salah satu SMK di Jakarta Utara yang masih menggunakan sistem informasi secara manual, salah satunya untuk pengolahan nilai raport siswa. Dimana dengan sistem pengolahan raport yang masih menggunakan sistem manual dapat mengakibatkan penyajian laporan data nilai siswa belum dapat dilakukan secara cepat dan akurat, sehingga dapat terjadinya kesalahan dalam proses penginputan dan pengolahan nilai siswa. Begitu juga masih sulitnya para guru untuk melakukan penginputan nilai dan kepala sekolah untuk melihat data akademik siswa. Belum adanya aplikasi yang dapat membantu tentang pengolahan data akademik siswa, sehingga kurangnya keakuratan data, efesiensi kerja serta masih adanya kesalahan yang terjadi selama proses olah data.

Dengan harapan mempermudah kinerja mulai dari penginputan data siswa sampai dengan pengolahan nilai siswa dengan sistem yang sudah terkomputerisasi dan efektifitas kerja dapat dimaksimalkan, serta pengaksesan data dapat dilakukan secara cepat dan efisien.

\section{METODE PENELITIAN}

1. Analisa Kebutuhan Software

Pada sistem informasi pengolahan nilai pada SMK Tanjung Priok 1 Jakarta ini penulis menggunakan tiga user dimana usernya terdiri dari Pemilik, Kepala Sekolah, Guru. Dimana nanti untuk Pemilik dapat menambahkan data guru, data kelas, data pelajaran serta melihat data guru, data siswa dan melihat laporan nilai siswa. Untuk Kepala Sekolah dapat menginput hanya dapat melihat data nilai siswa dan data siswa. Sedangkan untuk Guru hanya dapat mengolah data nilai siswa.

2. Desain

Pada tahapan desain penulis menggunakan software yaitu Microsoft Visual Basic 6.0 dan database SQL Server Enterprise yang dijalankan melalui browser pada sistem operasi Windows $X P$ professional atau Windows 7. Alat pendukung lain yang digunakan adalah $U M L$ (Unifield Modeling Languange) sebagai software architecture system serta ERD (Entity Relationship Diagram) untuk menggambarkan hubungan antar data.

\section{Code Generation}

Pada tahapan ini penulis akan menggunakan bahasa program Visual Basic yang merupakan salah satu program berbasis terstruktur dan dapat dilakukan instalshield pada komputer yang akan digunakan untuk menjalankan program.

4. Testing

Penulis menggunakan blackbox testing, yaitu tahapan dimana pengetesan

dari mulai login user, menu utama mulai dari input data guru, input data siswa, input data user, input data kelas, input data pelajaran, input nilai siswa sampai dengan pembuatan laporan data guru, laporan data siswa dan laporan data nilai.

\section{A. Pengertian Sistem Informasi}

Menurut Alter dalam (Mulyanto, 2009) "Sistem informasi adalah kombinasi antar prosedur kerja, informasi, orang dan teknologi informasi yang diorganisasikan untuk mencapai tujuan dalam sebuah organisasi”.

Menurut (Kristanto, 2008) "Sistem informasi adalah sekumpulan prosedur organisasi yang pada saat sedang dilaksanakan akan memberikan informasi bagi pengambil keputusan untuk mengendalikan organisasi”.

\section{B. Pengertian Akademik}

Menurut (Setiyawan, Purnama, \& Sukadi, 2013) "Akademik adalah kegiatan yang dilakukan di dalam lingkungan dunia pendidikan yang berhubungan dengan proses belajar mengajar”.

\section{Sistem Informasi Akademik}

Menurut (Setiyawan et al., 2013) "Sistem informasi akademik merupakan sistem yang memberikan layanan informasi berupa data yang berhubungan dengan data akademik".

\section{Konsep Dasar Pemrograman}

Menurut (Kurniadi, 2004) "Visual Basic 6.0 merupakan bahasa yang cukup mudah di pelajari bagi pemula". Bahasa ini menyediakan kesederhanaan dan kemudahan pemakai tanpa mengabaikan kinerja atau fasilitas yang menyebabkan windows menjadi lingkungan kerja yang menyenangkan database. Pemrograman visual basic juga menyediakan fasilitas untuk pemrograman yang menggunakan database. Pemrograman database pada program visual basic menggunakan Microsoft Access sebagai format standar.

\section{E. Unified Modelling Language (UML)}

Menurut (Fowler, 2005) "Unified Modeling Language (UML) merupakan keluarga notasi grafis yang didukung oleh meta-model tunggal, yang membantu pendeskripsian dan desain sistem perangkat lunak, khususnya sistem yang dibangun menggunakan pemrograman berorientasi objek (OO)". Yang termasuk dalam diagram UML diantaranya: 
a. Activity Diagram

Activity diagram adalah teknik atau suatu cara untuk menggambarkan logika prosedural, proses bisnis maupun jalur kerja program (Fowler, 2005). Diagram ini mirip dengan sebuah diagram alir, tetapi terdapat perbedaan prinsip antara diagram ini dan notasi diagram alir, diagram ini mendukung behavior parallel sedangkan diagram alir tidak mendukungnya.

b. Use Case Diagram

Use Case adalah teknik untuk merekam atau menyimpan persyaratan fungsional sebuah sistem (Fowler, 2005). Use case mendeskripsikan atau menjelaskan interaksi tipikal antara para pengguna sistem dengan sistem itu sendiri, dengan memberikan sebuah narasi tentang bagaimana sistem tersebut digunakan.

c. Component Diagram

Component diagram terdapat sebuah perdebatan yang selalu merebak luas dalam komunitas $\mathrm{OO}$ tentang perbedaan antara sebuah komponen dan class biasa (Fowler, 2005).

d. Deployment Diagram

Deployment diagram merupakan sebuah diagram yang menunjukkan susunan fisik sebuah sistem, menunjukkan bagian perangkat lunak yang berjalan pada perangkat keras (Fowler, 2005). Hal yang paling utama dalam diagram ini adalah pusat-pusat yang dihubungkan oleh jalur komunikasi.

\section{F. Entity Relationship Diagram (ERD)}

Menurut (Ladjamuddin, 2013) "Entity Relation Diagram (ERD) adalah model jaringan yang menggunakan susunan data yang disimpan dalam sebuah sistem secara abstrak".

\section{G. Logical Record Structure (LRS)}

Menurut (Fridayanthie \& Mahdiati, 2016) "Logical Record Structure (LRS) adalah representasi atau cabang dari struktur record-record pada tabeltabel yang terbentuk dari hasil antar himpunan entitas"

\section{HASIL DAN PEMBAHASAN}

\section{Proses Bisnis Sistem Berjalan}

1. Bagian Tata Usaha memberikan buku absensi siswa kepada sekertaris kelas. Setiap hari pada jam pertama belajar sekertaris kelas memberikan absen kepada guru untuk mencatat kehadiran dan ketidak hadiran siswa pada buku absensi. Lalu setelah mengabsen guru memberikan absen kepada sekertaris kelas untuk selanjutnya diberikan kepada wali kelas untuk di buatkan rekap absen di akhir semester.

2. Setiap mata pelajaran yang diajarkan guru memberikan tugas dan ulangan harian kepada siswa yang selanjutnya diperiksa oleh guru masing - masing dan setelah itu guru memberikan nilai dan mencatat hasil nilai pada lembar rekap nilai dan kemudian selanjutnya diberikan ke wali kelas untuk dibuatkan rekap nilai untuk di akhir semester.

3. Setelah wali kelas menerima data absen dari sekertaris dan data nilai dari guru lalu wali kelas membuat rekap absen dan nilai. Selanjutnya wali kelas akan mencatat nilai dan absen berdasarkan rekapitulasi kedalam buku raport. Buku raport lalu diberikan kepada kepala sekolah untuk di setujui dan di berikan kepada wakil kepala sekolah bidang kurikulum untuk diarsipkan. Setelah buku raport disetujui kepala sekolah, wali kelas kemudian memberikan hasil raport kepada orang tua siswa.

\section{Activity Diagram}

Activity Diagram Proses Absensi Siswa

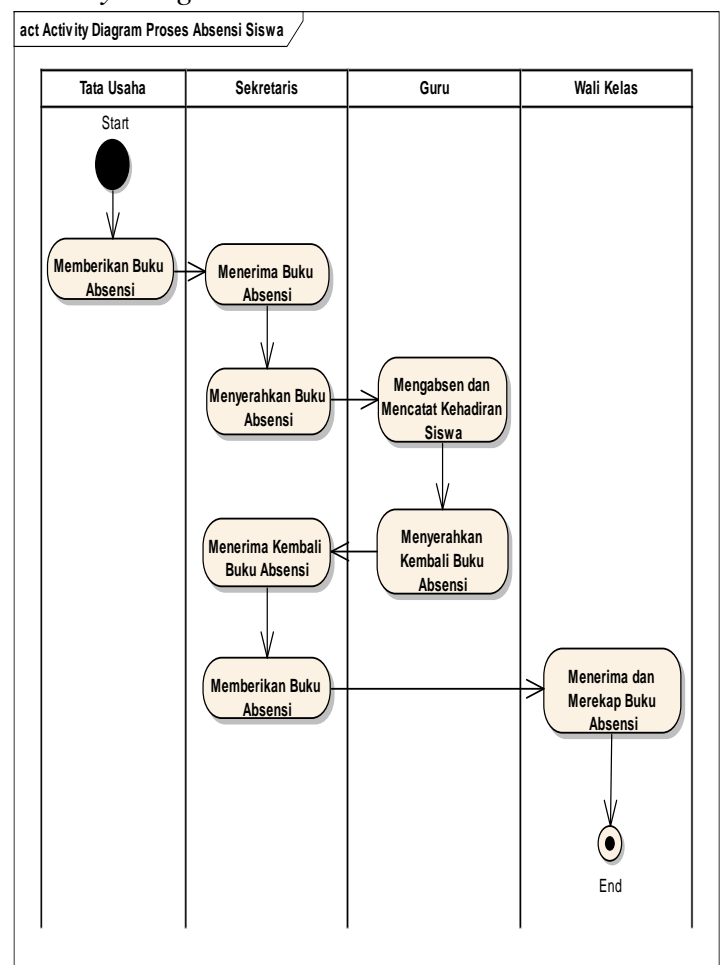

Sumber : Hasil Penelitian

Gambar 1. Activity Diagram Proses Absensi Siswa 
Activity Diagram Proses Nilai Siswa

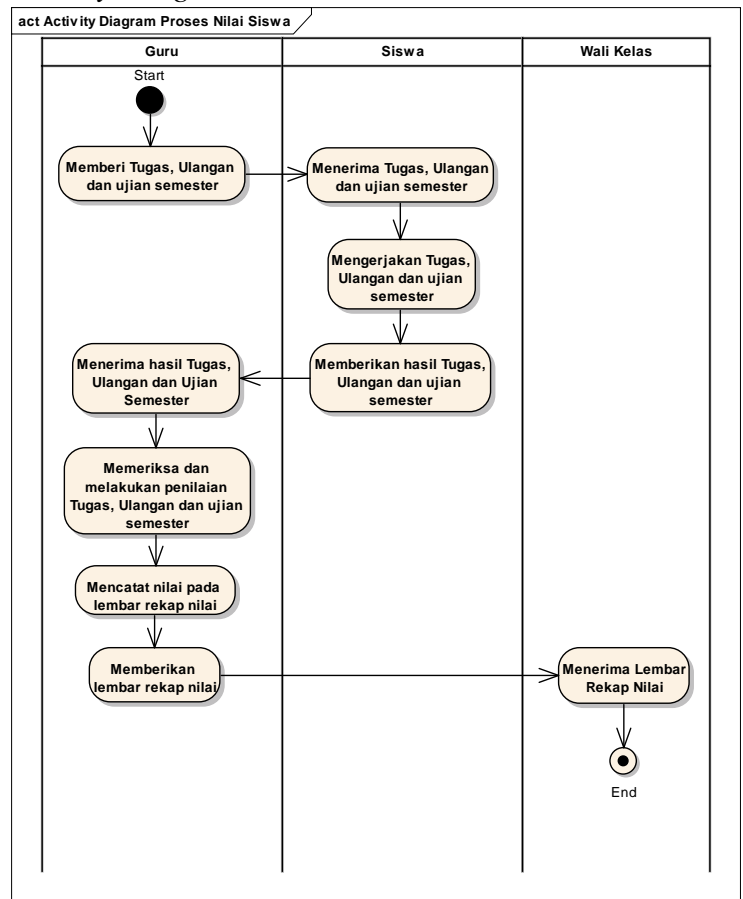

Sumber : Hasil Penelitian

Gambar 2. Activity Diagram Proses Nilai Siswa

Activity Diagram Proses Pembuatan Buku Raport

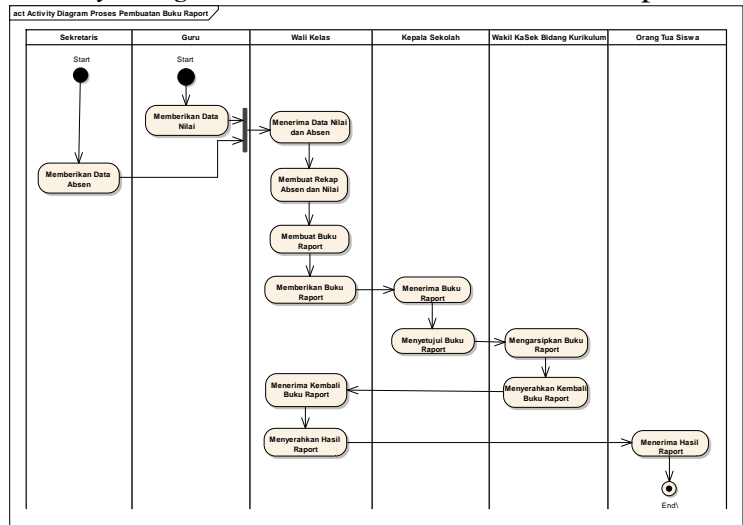

Sumber : Hasil Penelitian

Gambar 3. Activity Diagram Proses Pembuatan

Buku Raport

\section{Analisa Kebutuhan}

Program sistem informasi pada SMK Tanjung Priok 1 belum terkomputerisasi, untuk lebih efisien dibuatlah aplikasi dengan menggunakan beberapa user. Berikut ini adalah spesifikasi kebutuhan (system requirement) dari aplikasi sistem informasi akademik.

Akses TU :

A1. TU dapat melakukan Login

A2. TU dapat mengolah data guru

A3. TU dapat mengolah data kelas

A4. TU dapat mengolah data pelajaran

A5. TU dapat mengolah data jadwal

A6. TU dapat mengolah data siswa
A7. TU dapat mengolah data user

A8. TU dapat mengolah data jurusan

A9. TU dapat melakukan exit

Akses Kepala Sekolah :

B1. Kepala Sekolah dapat melakukan Login

B2. Kepala Sekolah dapat memproses nilai

B3. Kepala Sekolah dapat mencetak laporan

B4. Kepala Sekolah dapat melakukan exit

Akses Wakil Kepala Sekolah :

C1. Wakil Kepala Sekolah dapat melakukan Login

C2. Wakil Kepala Sekolah dapat mengolah data jadwal

C3. Wakil Kepala Sekolah dapat memproses nilai

C4. Wakil Kepala Sekolah dapat mencetak laporan

C5. Wakil Kepala Sekolah melakukan exit

Akses Wali Kelas :

D1. Wali Kelas dapat melakukan Login

D2. Wali Kelas dapat memproses absen

D3. Wali Kelas dapat memproses nilai

D4. Wali Kelas dapat mencetak laporan absen dan laporan nilai

D5. Wali Kelas dapat melakukan exit

Akses Guru :

E1. Guru dapat melakukan Login

E2. Guru dapat memproses nilai

E3. Guru dapat melakukan exit

\section{Use Case Diagram}

Use Case Diagram Sisfo Akademik Akses TU

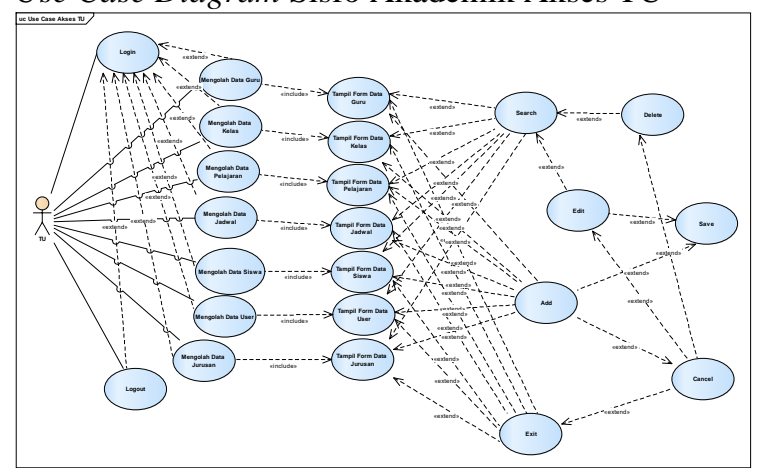

Sumber : Hasil Penelitian

Gambar 4. Use Case Diagram Akses TU

Tabel Deskripsi Use Case Sisfo Akademik Akses TU

Tabel 1. Deskripsi Use Case Akses TU

\section{Use Case Narative Akses TU}

\begin{tabular}{|l|l|}
\hline Tujuan & $\begin{array}{l}\text { Aktor dapat melihat data } \\
\text { yang ada pada akses TU }\end{array}$ \\
\hline Deskripsi & $\begin{array}{l}\text { Sistem ini memungkinkan } \\
\text { aktor untuk dapat }\end{array}$ \\
mengakses mengolah data \\
guru, mengolah data kelas, \\
mengolah data pelajaran, \\
mengolah data jadwal, \\
mengolah data siswa, \\
\hline
\end{tabular}




\begin{tabular}{|c|c|}
\hline & $\begin{array}{l}\text { mengolah data user, } \\
\text { mengolah data jurusan lewat } \\
\text { aplikasi program }\end{array}$ \\
\hline \multicolumn{2}{|l|}{ Skenario Utama } \\
\hline Aktor & TU \\
\hline Kondisi Awal & $\begin{array}{l}\text { Aktor membuka aplikasi } \\
\text { akses TU }\end{array}$ \\
\hline Aksi Aktor & Reaksi Sistem \\
\hline $\begin{array}{l}\text { 1. Aktor memilih } \\
\text { mengolah data guru }\end{array}$ & $\begin{array}{l}\text { Sistem ini menampilkan } \\
\text { informasi mengolah data } \\
\text { guru }\end{array}$ \\
\hline $\begin{array}{l}\text { 2. Aktor memilih } \\
\text { mengolah data kelas }\end{array}$ & $\begin{array}{l}\text { Sistem ini menampilkan } \\
\text { informasi mengolah data } \\
\text { kelas }\end{array}$ \\
\hline $\begin{array}{lr}\text { 3. Aktor } & \text { memilih } \\
\text { mengolah } & \text { data } \\
\text { pelajaran } & \\
\end{array}$ & $\begin{array}{l}\text { Sistem ini menampilkan } \\
\text { informasi mengolah data } \\
\text { pelajaran }\end{array}$ \\
\hline $\begin{array}{lr}\text { 4. Aktor } & \text { memilih } \\
\text { mengolah } & \text { data } \\
\text { jadwal } & \\
\end{array}$ & $\begin{array}{l}\text { Sistem ini menampilkan } \\
\text { informasi mengolah data } \\
\text { jadwal }\end{array}$ \\
\hline $\begin{array}{lr}\text { 5. Aktor } & \text { memilih } \\
\text { mengolah } & \text { data } \\
\text { siswa } & \\
\end{array}$ & $\begin{array}{l}\text { Sistem ini menampilkan } \\
\text { informasi mengolah data } \\
\text { siswa }\end{array}$ \\
\hline $\begin{array}{l}\text { 6. Aktor memilih } \\
\text { mengolah data user }\end{array}$ & $\begin{array}{l}\text { Sistem ini menampilkan } \\
\text { informasi mengolah data } \\
\text { user }\end{array}$ \\
\hline $\begin{array}{lr}\text { 7. Aktor } & \text { memilih } \\
\text { mengolah } & \text { data } \\
\text { jurusan } & \\
\end{array}$ & $\begin{array}{l}\text { Sistem ini menampilkan } \\
\text { informasi mengolah data } \\
\text { jurusan }\end{array}$ \\
\hline Kondisi Akhir & $\begin{array}{llr}\text { Apabila perintah } & \text { sesuai } \\
\text { maka sistem } & \text { akan } \\
\text { menampilkan apa } & \text { yang } \\
\text { diinginkan } & & \\
\end{array}$ \\
\hline
\end{tabular}

Use Case Diagram Sisfo Akademik Akses Kepala Sekolah

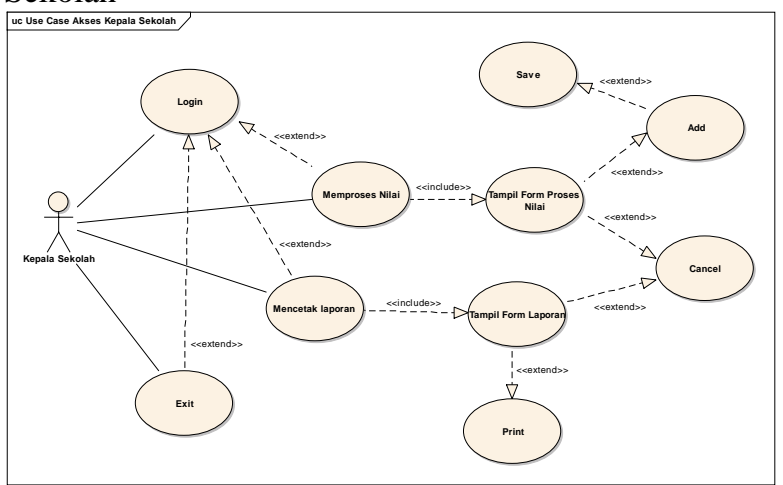

Sumber : Hasil Penelitian

Gambar 5. Use Case Diagram Akses Kepala

\section{Sekolah}

Tabel Deskripsi Use Case Sisfo Akademik Akses Kepala Sekolah Tabel 2. Deskripsi Use Case Akses Kepala Sekolah

\begin{tabular}{|l|l|}
\hline \multicolumn{2}{|c|}{ Use Case Narative Akses Kepala Sekolah } \\
\hline Tujuan & $\begin{array}{l}\text { Aktor dapat melihat data } \\
\text { yang ada pada akses Kepala } \\
\text { Sekolah }\end{array}$ \\
\hline
\end{tabular}

\begin{tabular}{|l|l|}
\hline Deskripsi & $\begin{array}{l}\text { Sistem ini memungkinkan } \\
\text { aktor untuk dapat } \\
\text { mengakses memproses nilai, } \\
\text { mencetak laporan lewat } \\
\text { aplikasi program }\end{array}$ \\
\hline Skenario Utama & Kepala Sekolah \\
\hline Aktor & $\begin{array}{l}\text { Aktor membuka aplikasi } \\
\text { akses Kepala Skeolah }\end{array}$ \\
\hline $\begin{array}{l}\text { Kondisi Awal } \\
\text { Reaksi Sistem }\end{array}$ \\
\hline $\begin{array}{l}\text { Aksi Aktor Aktor memilih } \\
\text { memproses nilai }\end{array}$ & $\begin{array}{l}\text { Sistem ini menampilkan } \\
\text { informasi proses nilai }\end{array}$ \\
\hline $\begin{array}{l}\text { 2. Aktor memilih } \\
\text { mencetak laporan }\end{array}$ & $\begin{array}{l}\text { Sistem ini menampilkan } \\
\text { informasi melihat dan } \\
\text { mencetak laporan }\end{array}$ \\
\hline $\begin{array}{l}\text { Kondisi Akhir } \\
\text { Apabila perintah sesuai } \\
\text { maka sistem akan } \\
\text { menampilkan apa yang } \\
\text { diinginkan }\end{array}$ \\
\hline
\end{tabular}

Use Case Diagram Sisfo Akademik Akses Wakil Kepala Sekolah

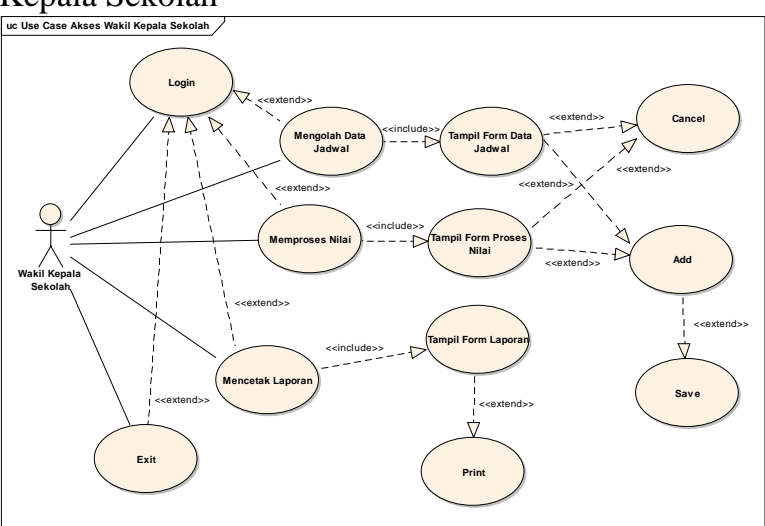

Sumber : Hasil Penelitian

Gambar 6. Use Case Diagram Akses Wakil Kepala Sekolah

Tabel Deskripsi Use Case Sisfo Akademik Akses Wakil Kepala Sekolah

Tabel 3. Deskripsi Use Case Akses Wakil Kepala Sekolah

Use Case Narative Akses Wakil Kepala Sekolah

\begin{tabular}{|l|l|}
\hline Tujuan & $\begin{array}{l}\text { Aktor dapat melihat data } \\
\text { yang ada pada akses Wakil } \\
\text { Kepala Sekolah }\end{array}$ \\
\hline Deskripsi & $\begin{array}{l}\text { Sistem ini memungkinkan } \\
\text { aktor untuk dapat } \\
\text { mengakses mengolah data } \\
\text { jadwal, memproses nilai, } \\
\text { mencetak laporan lewat } \\
\text { aplikasi program }\end{array}$ \\
\hline Skenario Utama & \multicolumn{2}{|l|}{} \\
\hline Aktor & $\begin{array}{l}\text { Aktor membuka aplikasi } \\
\text { akses Wakil Kepala Skeolah }\end{array}$ \\
\hline Kondisi Awal & Reaksi Sistem \\
\hline Aksi Aktor &
\end{tabular}




\begin{tabular}{|c|l|l|}
\hline $\begin{array}{l}\text { 1. Aktor memilih } \\
\text { mengolah data } \\
\text { jadwal }\end{array}$ & $\begin{array}{l}\text { Sistem ini menampilkan } \\
\text { informasi mengolah data } \\
\text { jadwal }\end{array}$ \\
\hline $\begin{array}{c}\text { 2. Aktor memilih } \\
\text { memproses nilai }\end{array}$ & $\begin{array}{l}\text { Sistem ini menampilkan } \\
\text { informasi proses nilai }\end{array}$ \\
\hline $\begin{array}{c}\text { 3. Aktor memilih } \\
\text { mencetak laporan }\end{array}$ & $\begin{array}{l}\text { Sistem ini menampilkan } \\
\text { informasi melihat dan } \\
\text { mencetak laporan }\end{array}$ \\
\hline Kondisi Akhir & $\begin{array}{l}\text { Apabila perintah sesuai } \\
\text { maka sistem akan } \\
\text { menampilkan apa yang } \\
\text { diinginkan }\end{array}$ \\
\hline
\end{tabular}

Use Case Diagram Sisfo Akademik Akses Wali Kelas

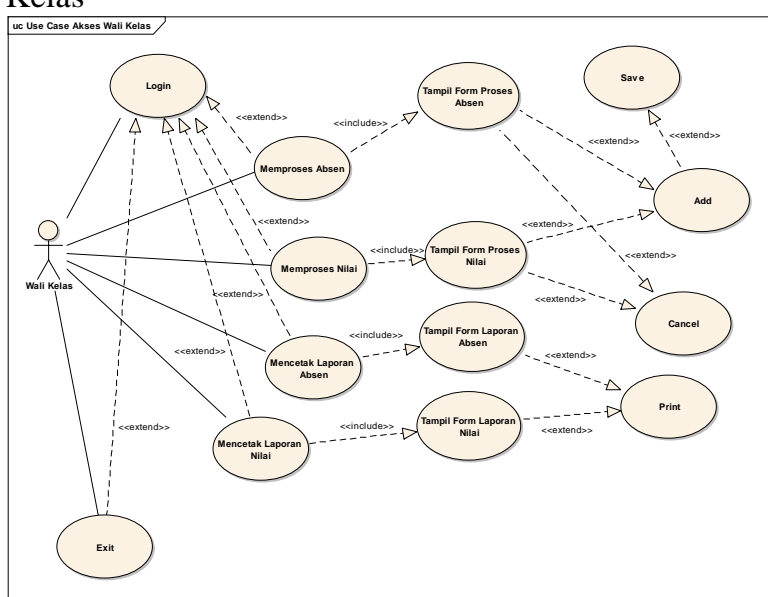

Sumber : Hasil Penelitian

Gambar 7.l Use Case Diagram Akses Wali Kelas

Tabel Deskripsi Use Case Sisfo Akademik Akses Wali Kelas

Tabel 4. Deskripsi Use Case Akses Wali Kelas

\begin{tabular}{|l|l|}
\hline \multicolumn{2}{|c|}{ Use Case Narative Akses Wali Kelas } \\
\hline Tujuan & $\begin{array}{l}\text { Aktor dapat melihat data } \\
\text { yang ada pada akses Wali } \\
\text { Kelas }\end{array}$ \\
\hline Deskripsi & $\begin{array}{l}\text { Sistem ini memungkinkan } \\
\text { aktor untuk dapat } \\
\text { mengakses mengolah data } \\
\text { jadwal, memproses nilai, } \\
\text { mencetak laporan lewat } \\
\text { aplikasi program }\end{array}$ \\
\hline Skenario Utama & \multicolumn{1}{|c|}{ Wakil Kepala Sekolah } \\
\hline Aktor & $\begin{array}{l}\text { Aktor membuka aplikasi } \\
\text { akses Wakil Kepala Skeolah }\end{array}$ \\
\hline $\begin{array}{l}\text { Kondisi Awal } \\
\text { Reaksi Sistem }\end{array}$ \\
\hline $\begin{array}{l}\text { Aksi Aktor memilih } \\
\text { memproses Absen }\end{array}$ & $\begin{array}{l}\text { Sistem ini menampilkan } \\
\text { informasi proses absen }\end{array}$ \\
\hline $\begin{array}{l}\text { 2. Aktor memilih } \\
\text { memproses nilai }\end{array}$ & $\begin{array}{l}\text { Sistem ini menampilkan } \\
\text { informasi proses nilai }\end{array}$ \\
\hline $\begin{array}{l}\text { 3. Aktor memilih } \\
\text { mencetak laporan } \\
\text { Absen }\end{array}$ & $\begin{array}{l}\text { Sistem ini menampilkan } \\
\text { informasi melihat dan } \\
\text { mencetak laporan Absen }\end{array}$ \\
\hline \multicolumn{2}{|c|}{ mat } \\
\hline
\end{tabular}

\begin{tabular}{|l|lr|}
\hline $\begin{array}{c}\text { 4. Aktor memilih } \\
\text { mencetak laporan }\end{array}$ & $\begin{array}{l}\text { Sistem ini menampilkan } \\
\text { informasi melihat dan } \\
\text { Nilai }\end{array}$ & mencetak laporan Nilai \\
\hline Kondisi Akhir & Apabila perintah sesuai \\
& maka sistem akan \\
& $\begin{array}{l}\text { menampilkan apa yang } \\
\text { diinginkan }\end{array}$ \\
\hline
\end{tabular}

Use Case Diagram Sisfo Akademik Akses Guru

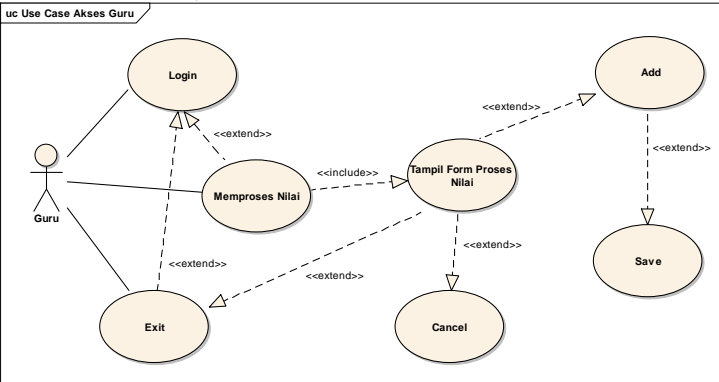

Sumber : Hasil Penelitian

Gambar 8. Use Case Diagram Akses Guru

Tabel Deskripsi Use Case Sisfo Akademik Akses Guru

Tabel 5. Deskripsi Use Case Akses Guru

\begin{tabular}{|l|l|}
\hline \multicolumn{2}{|c|}{ Use Case Narative Akses Guru } \\
\hline Tujuan & $\begin{array}{l}\text { Aktor dapat melihat data } \\
\text { yang ada pada akses Guru }\end{array}$ \\
\hline Deskripsi & $\begin{array}{l}\text { Sistem ini memungkinkan } \\
\text { aktor untuk dapat } \\
\text { mengakses memproses nilai } \\
\text { lewat aplikasi program }\end{array}$ \\
\hline Skenario Utama & Guru \\
\hline Aktor & $\begin{array}{l}\text { Aktor membuka aplikasi } \\
\text { akses Guru }\end{array}$ \\
\hline $\begin{array}{l}\text { Kondisi Awal } \\
\text { Reaksi Sistem }\end{array}$ \\
\hline Aksi Aktor & $\begin{array}{l}\text { Sistem ini menampilkan } \\
\text { informasi proses nilai }\end{array}$ \\
\hline $\begin{array}{l}\text { 1. Aktor memilih } \\
\text { memproses nilai }\end{array}$ & $\begin{array}{l}\text { Apabila perintah sesuai } \\
\text { maka sistem akan } \\
\text { menampilkan apa yang } \\
\text { diinginkan }\end{array}$ \\
\hline \begin{tabular}{l} 
Kondisi Akhir \\
\hline
\end{tabular}
\end{tabular}


Entity Relationship Diagram (ERD)

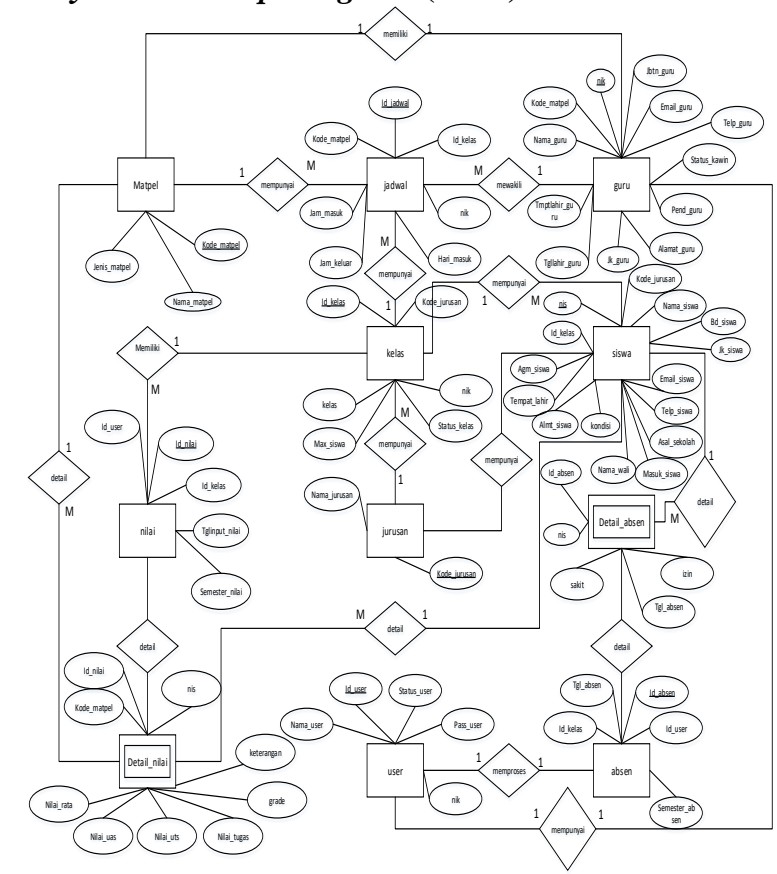

Sumber : Hasil Penelitian

Gambar 9. ERD (Entity Relationship Diagram)

\section{Logical Record Structure}

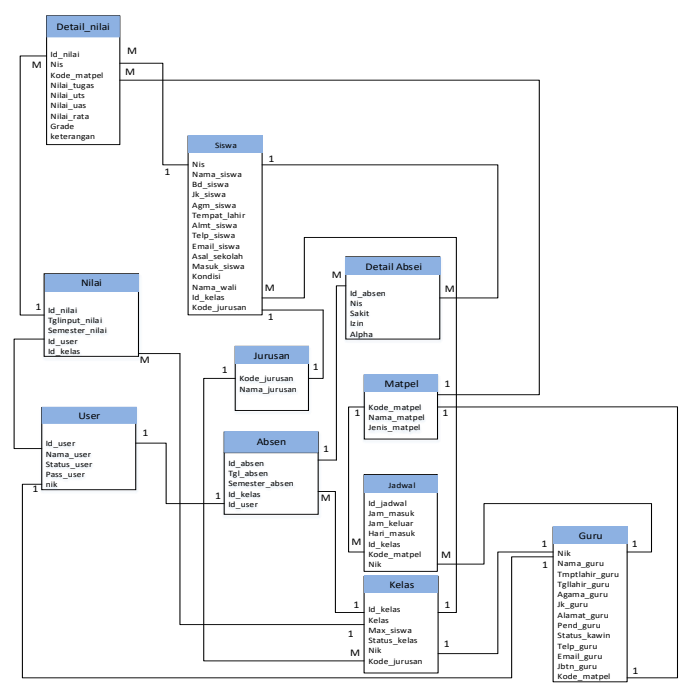

Sumber : Hasil Penelitian

Gambar 10. LRS (Logical Record Structure)

\section{Deployment Diagram}

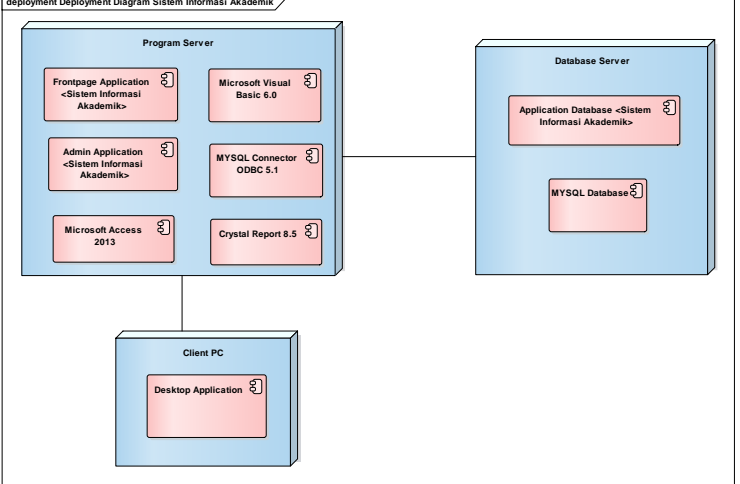

Sumber : Hasil Penelitian

Gambar 11. Deployment Diagram

\section{User Interface}

Tampilan User Interface Form Menu Utama

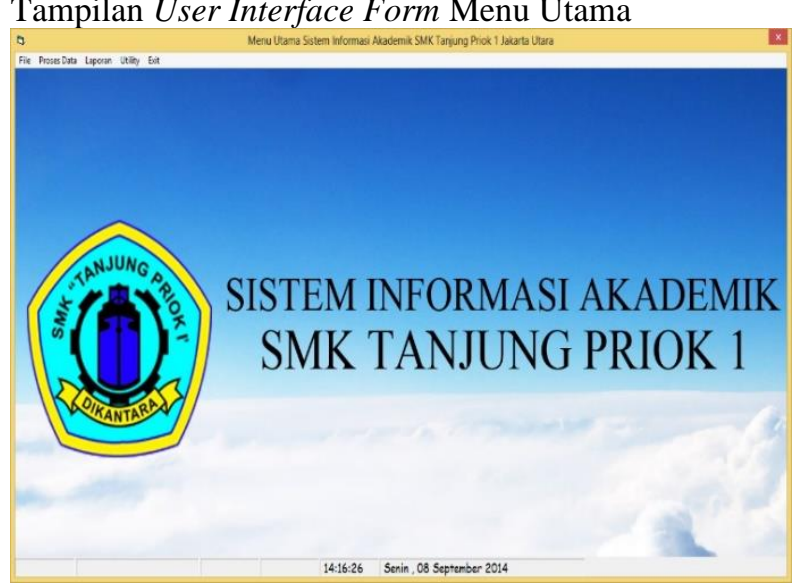

Sumber : Hasil Penelitian

Gambar 12. Tampilan Form Menu Utama

Tampilan User Interface Form Guru

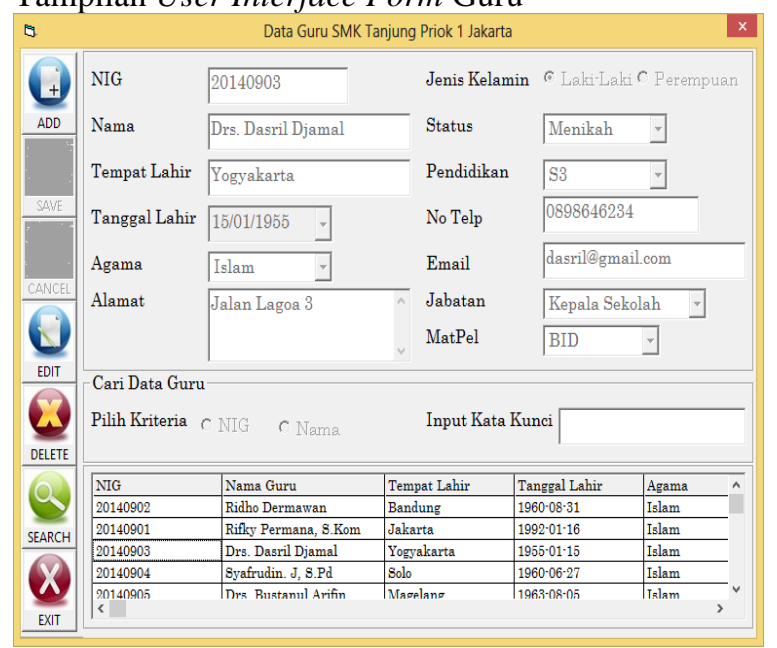

Sumber : Hasil Penelitian Gambar 13. Tampilan Form Data Guru 
Tampilan User Interface Form Data Kelas

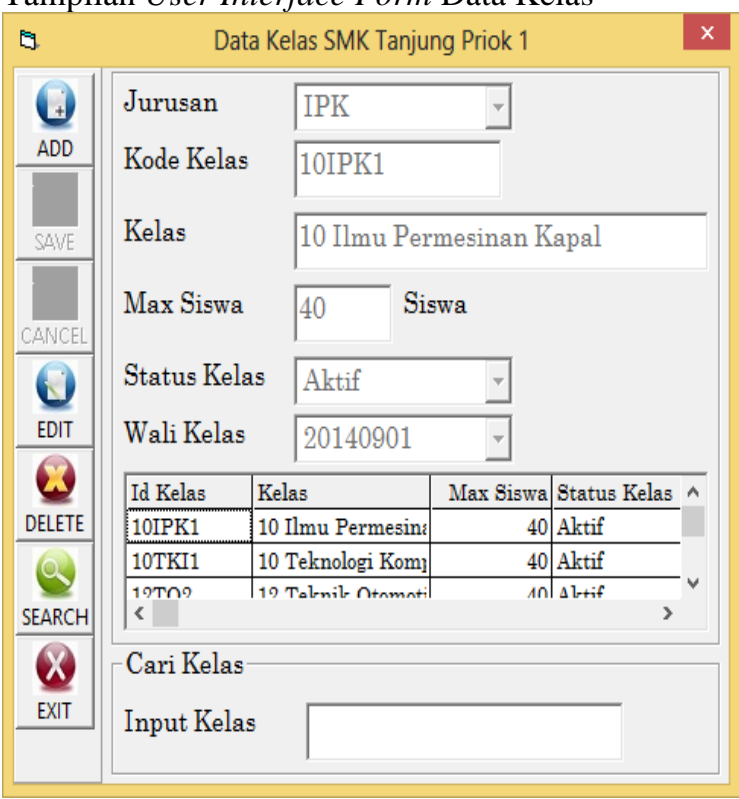

Sumber : Hasil Penelitian

Gambar 14. Tampilan Form Data Kelas

Tampilan User Interface Form Mata Pelajaran

\begin{tabular}{|c|c|c|c|c|}
\hline 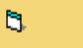 & \multicolumn{3}{|c|}{ Data Mata Pelajaran } & \\
\hline (4) & \multirow{2}{*}{ Kode Matpel } & \multicolumn{3}{|l|}{ MTK } \\
\hline$A D D$ & & \multirow{2}{*}{\multicolumn{3}{|c|}{ Matemtika }} \\
\hline \multirow[b]{2}{*}{ SAVE } & Nama Matpel & & & \\
\hline & Jenis Matpel & Adaptif & \multicolumn{2}{|l|}{ 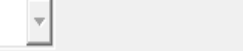 } \\
\hline \multirow{2}{*}{ CANCEL } & Kode Matpel & \multicolumn{2}{|c|}{ Nama Matpel } & Jenis Mat]^ \\
\hline & BID & \multicolumn{2}{|c|}{ Bahasa Indonesia } & Normatif \\
\hline U & MTK & \multicolumn{2}{|c|}{ Matemtika } & Adaptif \\
\hline EDIT & BIG & \multicolumn{2}{|c|}{ Bahasa Inggris } & Adaptif \\
\hline & IPS & \multicolumn{2}{|c|}{ Ilmu Pengetahuan Sosial } & Adaptif \\
\hline w) & IPA & \multicolumn{2}{|c|}{ Ilmu Pengetahuan Alam } & Adaptif \\
\hline DELETE & & \multicolumn{2}{|c|}{ Fisika } & Adaptif \\
\hline (W) & & $>$ \\
\hline SEARCH & \multirow{2}{*}{\multicolumn{4}{|c|}{$\begin{array}{l}\text { Cari Mata Pelajaran } \\
\text { Input Mata Pelajaran }\end{array}$}} \\
\hline$\frac{X}{\text { EXIT }}$ & & & & \\
\hline
\end{tabular}

Sumber : Hasil Penelitian

Gambar 15. Tampilan Form Data Mata Pelajaran
Tampilan User Interface Form Jadwal

\begin{tabular}{|c|c|c|c|c|}
\hline$\theta$ & \multicolumn{3}{|c|}{ Data Jadwal SMK Tanjung Priok 1} & $x$ \\
\hline \multirow[b]{2}{*}{$A D D$} & \multirow{2}{*}{$\begin{array}{l}\text { Id Jadwal } \\
\text { Kode Matpel }\end{array}$} & \multicolumn{2}{|l|}{002} & \\
\hline & & BID & 7 & \\
\hline \multirow[b]{2}{*}{ SAVE } & Id Kelas & 10IPK1 & 7 & \\
\hline & & Selasa & 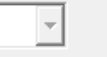 & \\
\hline \multirow{2}{*}{ CANCEL } & Jam Masuk & 07:00 ב & & \\
\hline & Jam Keluar & 07:45 & & \\
\hline \multirow{3}{*}{ EDIT } & Nig & 20140902 & $\nabla$ & \\
\hline & Id J $\mathrm{I}$ Id Kelas & Kode Matpel & Nik & $\operatorname{Jam}^{\wedge}$ \\
\hline & \begin{tabular}{|l|l}
001 & $10 I P K 1$ \\
\end{tabular} & MTK & 20140901 & $07: 01$ \\
\hline \multirow[b]{3}{*}{ DELETE } & \begin{tabular}{|l|l|}
002 & $10 \mathrm{IPK} 1$ \\
\end{tabular} & BID & 20140902 & $07: 01$ \\
\hline & \begin{tabular}{|l|l|}
003 & $12 \mathrm{TO} 2$ \\
\end{tabular} & MTK & 20140905 & 09:1: \\
\hline & 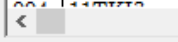 & & \multicolumn{2}{|c|}{ Cari Data Jadwal } \\
\hline SEARCH & {$\left[\begin{array}{l}\text { Cari Data Ja } \\
\curvearrowright \text { Filter By I } \\
\curvearrowright \text { Filter By I } \\
\curvearrowright \text { Filter By I }\end{array}\right.$} & $\begin{array}{l}\text { val } \\
\text { Gas }\end{array}$ & & \\
\hline CLOSE & Input Keywo & & & \\
\hline
\end{tabular}

Sumber : Hasil Penelitian

Gambar 16. Tampilan Form Data Jadwal

Tampilan User Interface Form Jurusan

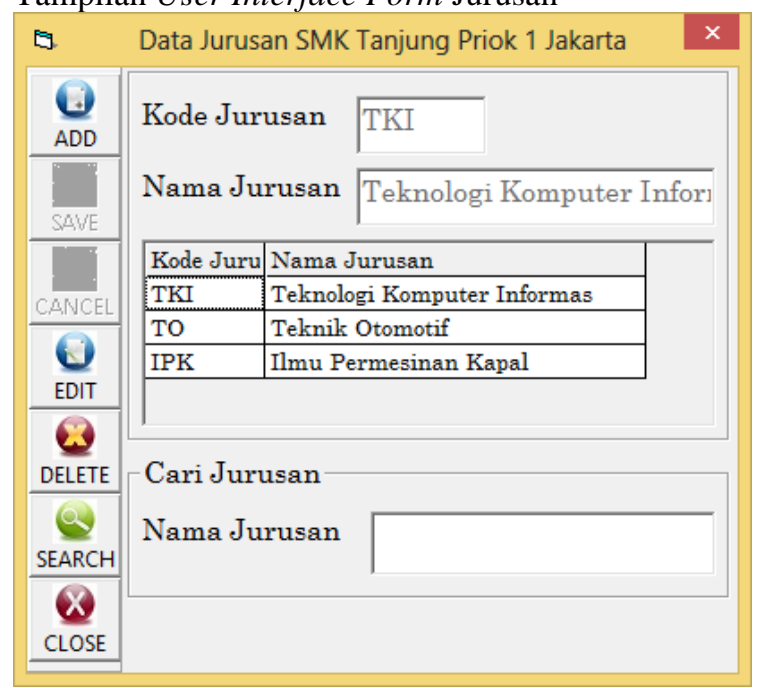

Sumber : Hasil Penelitian

Gambar 17. Tampilan Form Data Jurusan 
Tampilan User Interface Form Data Siswa

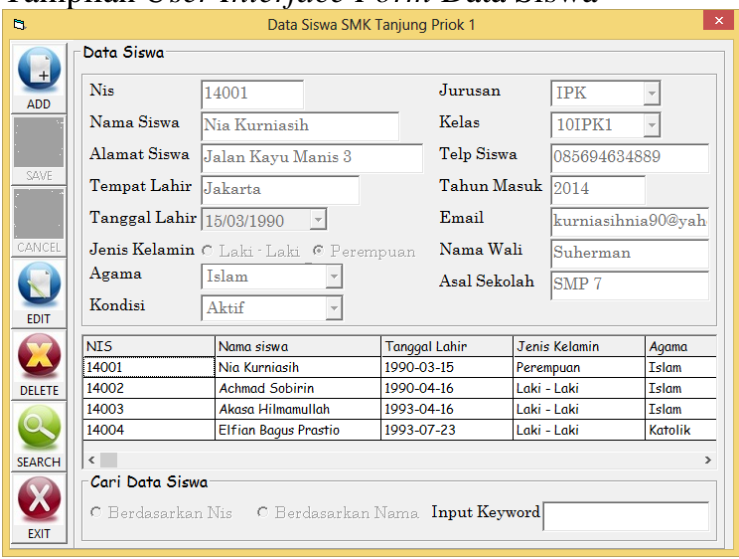

Sumber : Hasil Penelitian

Gambar 18. Tampilan Form Data Siswa

Tampilan User Interface Form Data User

\begin{tabular}{|c|c|c|c|c|}
\hline 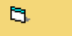 & \multicolumn{4}{|c|}{ Data User SMK Tanjung Priok 1} \\
\hline \multirow{2}{*}{$\frac{C}{A D D}$} & Status User & Pengajar & \multicolumn{2}{|l|}{ 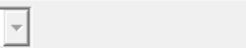 } \\
\hline & NIK & \multicolumn{3}{|l|}{20140902} \\
\hline & Jabatan & \multicolumn{3}{|l|}{ Guru } \\
\hline & Id User & \multicolumn{3}{|l|}{ PPR02 } \\
\hline & Nama User & \multicolumn{3}{|c|}{ Ridho Dermawan } \\
\hline & Password & \multicolumn{3}{|l|}{$5 \mathrm{mkpr} 10 \mathrm{k}$} \\
\hline \multirow{3}{*}{ DELETE } & Id User & Nama User & Status & Password \\
\hline & PPR02 & Ridho Dermaw: & Pengajar & $5 \mathrm{mkpr} 10 \mathrm{k}$ \\
\hline & PPR01 & Rifky Permana & Pengajar & $5 \mathrm{mkpr} 10 \mathrm{k}$ \\
\hline$(4)$ & APR01 & Anonymous & Admin & admin \\
\hline SEARCH & \\
\hline X) & \multirow{2}{*}{\multicolumn{4}{|c|}{$\begin{array}{l}\text { Cari Data User } \\
\text { Input Id User }\end{array}$}} \\
\hline EXIT & & & & \\
\hline
\end{tabular}

Sumber : Hasil Penelitian

Gambar 19. Tampilan Form Data User

Tampilan User Interface Form Proses Absen

\begin{tabular}{|c|c|c|c|c|c|}
\hline \multicolumn{2}{|l|}{ Q } & \multicolumn{3}{|c|}{ Proses Absen SMK Tanjung Priok 1 Jakarta } & $x$ \\
\hline Id Absen & AGJL1402 & Id Use & & Tanggal Input & $08 / 09 / 2014$ \\
\hline \multicolumn{6}{|c|}{ Data Siswa } \\
\hline Id Kelas & $10 \mathrm{IPK} 1$ & \multirow[t]{2}{*}{$\nabla$ Kelas } & \multirow{2}{*}{10 Ilmu Permesi } & \multirow{2}{*}{$\begin{array}{l}\text { Semester } \\
\text { Nama Siswa }\end{array}$} & Ganjil \\
\hline Nis & 14001 & & & & Nia Kurniasih \\
\hline \multicolumn{2}{|c|}{ Data Absen } & \multirow{2}{*}{ Alpha } & \begin{tabular}{|l|l|} 
Id Absen & Nis \\
\end{tabular} & Sakit & \multirow[t]{3}{*}{ Izin } \\
\hline Sakit & Izin & & \multirow[b]{2}{*}{$<$} & & \\
\hline 9 & 9 & 9 & & & \\
\hline
\end{tabular}

Sumber : Hasil Penelitian

Gambar 20. Tampilan Form Proses Absen
Tampilan User Interface Form Proses Nilai

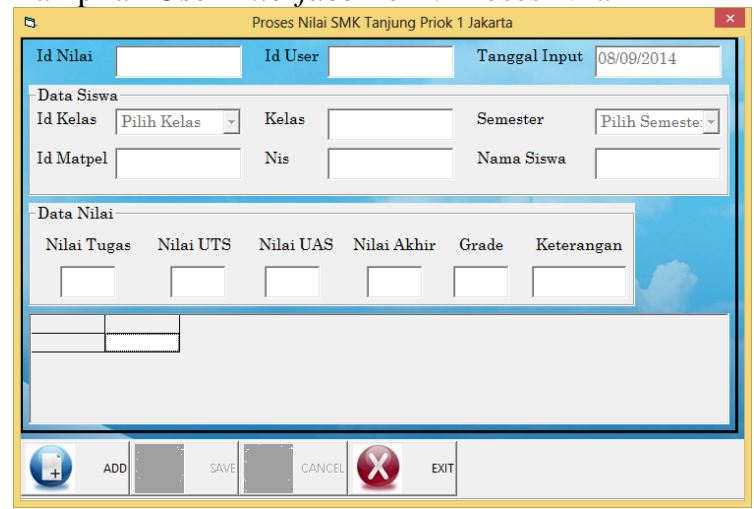

Sumber : Hasil Penelitian

Gambar 21. Tampilan Form Proses Nilai

Tampilan User Interface Laporan Data Absen

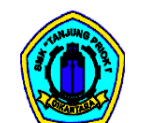

DATA ABSEN SMK TANJUNG PRIOK 1

Jal an Mangga No.3B Rt 006 Rw 08 Kelurahan Lagoa Kecamatan Koja Jakarta Utara 14270, Telp 021-4301192 Fax 021-43905185

\begin{tabular}{|c|c|c|c|c|c|c|}
\hline Id Absen & Nis & Nama_Siswa & Id Kelas & Sakit & Izin & Alpha \\
\hline AGJL1401 & & & & & & \\
\hline \multicolumn{2}{|c|}{14001} & Nia Kurnasih & 100 PRK1 & 0 & 0 & 0 \\
\hline
\end{tabular}

\section{Wali Kelas}

20140901

Sumber : Hasil Penelitian

Gambar 22. Tampilan Laporan Absen

Tampilan User Interface Laporan Nilai

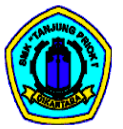

DATA NILAI SMK TANJNG PRIOK 1

Jalan Mangga No.3B Rt 006 Rw 08 Kelurahan Lagoa Kecamatan Koj Jakarta Utara 14270, Telp 021-4301192 Fax 021-43905185

\begin{tabular}{|c|l|l|l|l|r|l|l|}
\hline Nis & Kelas & Semester & Kode MP & Mata Pelajaran & Nilzi & Grade & K/BK \\
\hline 14001 & & & & & & & \\
\hline \multirow{3}{*}{} & 10 10PK1 & Ganjil & MTK & Matemika & 78 & B & K \\
& 10 IPK1 & Ganjil & BID & Bahasa Indonesia & 87 & A & K \\
\hline
\end{tabular}

Sumber : Hasil Penelitian

Gambar 23. Tampilan Laporan Nilai

\section{KESIMPULAN}

Pemanfaatan teknologi informasi yaitu dengan pembuatan aplikasi sistem informasi akademik berbasis desktop ini diharapkan dapat menjadi solusi dalam pengolahan data akademik secara efektif dan efisien. Dengan menggunakan sistem yang telah terkomputerisasi, SMK Tanjung Priok 1 diharapkan dapat mengurangi kesalahan-kesalahan yang terjadi, baik dalam proses pencatatan maupun pengolahan data akademik yang telah dilakukan. 


\section{REFERENSI}

Fowler, M. (2005). Panduan Singkat Tentang Bahasa Pemodelan Objek Standar. Yogyakarta: Andi.

Fridayanthie, E. W., \& Mahdiati, T. (2016). Rancang Bangun Sistem Informasi Permintaan Atk Berbasis Intranet (Studi Kasus: Kejaksaan Negeri Rangkasbitung). Jurnal Khatulistiwa Informatika, IV(June), 126-138. Retrieved from

https://ejournal.bsi.ac.id/ejurnal/index.php/kha tulistiwa/article/view/1264/1029

Kristanto, A. (2008). Perancangan Sistem Informasi dan Aplikasinya. Yogyakarta: Gava Media.

Kurniadi, A. (2004). Pemrograman Microsoft Visual Basic 6. Jakarta: Gramedia Jakarta.

Ladjamuddin, A. B. Bin. (2013). Analisis Dan Desain Sistem Informasi. Yogyakarta: Graha Ilmu.

Mulyanto, A. (2009). Sistem Informasi KONSEP \& APLIKASI. Yogyakarta: Pustaka Belajar.

Setiyawan, A., Purnama, B. E., \& Sukadi. (2013).
PEMBUATAN SISTEM INFORMASI

AKADEMIK BERBASIS WEB PADA

SEKOLAH MENENGAH ATAS NEGERI 1

NGADIROJO Andri Setiyawan, Bambang Eka

Purnama, Sukadi. Sistem Informasi Akademik Berbasis Web, 3, 1-5.

Sugiarti, D., \& Wardati, I. U. (2012). Sistem Informasi Akademik Sekolah Dasar AlMuhajirin Barehan Sidoharjo Pacitan. Journal Speed - Sentra Penelitian Engineering Dan Edukasi, 4(1), 18-27.

Wardani, S. K. (2013). Sistem Informasi Pengolahan Data Nilai Siswa Berbasis Web Pada Sekolah Menengah Kejuruan (Smk) Pgri 1 Pacitan. IJNS - Indonesian Journal on Networking and Security, 2(4), 12-19.

Widhiarso, Y., \& Riasti, B. K. (2013). Rancang Bangun Sistem Informasi Nilai Akademik Dan Prepensi Siswa Berbasis SMS Gateway Pada SDN Tulukan III. IJNS - Indonesian Journal on Networking and Security, 2(Laporan), 1-6. 